\title{
PENGEMBANGAN MEDIA PEMBELAJARAN INTERAKTIF PADA MATA KULIAH TEORI DAN PRAKTIK PLAMBING DI PROGRAM STUDI S1 PVKB UNJ
}

\author{
Nanda Dewi', R. Eka Murtinugraha', Riyan Arthur ${ }^{3}$ \\ ${ }^{1}$ Alumni PTB FT UNJ, nandadewikusumaw@gmail.com \\ ${ }^{2}$ Dosen PVKB FT UNJ, r ekomn@unj.ac.id \\ ${ }^{3}$ Dosen PVKB FT UNJ, arthur@uni.ac.id
}

\begin{abstract}
Abstrak
Penelitian ini merupakan penelitian pengembangan yang bertujuan untuk menghasilkan media pembelajaran interaktif pada mata kuliah Teori dan Praktik Plambing dengan berbantuan perangkat lunak Adobe Flash CS6.

Penelitian ini menggunakan metode penelitian Research and Development (R\&D) dengan model Borg \& Gall. Penelitian ini menggunakan angket sebagai instrumen pengumpulan data uji validasi dari ahli media, ahli materi dan penilaian mahasiswa yang sedang mengambil mata kuliah Teori dan Praktik Plambing.

Hasil validasi media pembelajaran mendapatkan persentase kelayakan sebesar 72,92\% dan yang berada pada kategori "Layak", dari hasil validasi ahli materi mendapatkan persentase kelayakan sebesar 86,90\% yang berada pada kategori "Sangat Layak" dan hasil penilaian mahasiswa mendapatkan persentase kelayakan sebesar 82,07\% yang berada pada kategori "Sangat Layak". Berdasarkan dari hasil tersebut dapat disimpulkan bahwa media pembelajaran yang dikembangkan layak digunakan untuk proses pembelajaran Teori dan Praktik Plambing di Program Studi Pendidikan Vokasional Konstruksi Bangunan.
\end{abstract}

Kata kunci : media pembelajaran interaktif, adobe flash, teori dan praktik plambing.

\section{THE DEVELOPMENT OF INTERACTIVE LEARNING MEDIA FOR CONCEPT AND PRACTICE OF PLUMBING SUBJECT IN VOCATIONAL EDUCATION OF BUILDING CONSTRUCTION STATE UNIVERSITY OF JAKARTA}

\author{
Nanda Dewi ${ }^{1}$, R. Eka Murtinugraha ${ }^{2}$, Riyan Arthur ${ }^{3}$ \\ ${ }^{1}$ Alumni of PVKB FT UNJ, nandadewikusumaw@gmail.com \\ ${ }^{2}$ Lecturer of PVKB FT UNJ, rekomn@unj.ac.id \\ ${ }^{3}$ Lecturer of PVKB FT UNJ, arthur@unj.ac.id
}

\begin{abstract}
This study is a development research that aims to develop an interactive learning media for concept and practice of Plumbing subject using Adobe Flash CS6.

This development research was using Borg \& Gall's model. This research using questionnaire as data collection instrument feasibility of the media through the validation by media experts, material expert and student assesment who join concept and practice of plumbing subject.

The results of validation learning media with the percentage feasibility $72,92 \%$ are in the "Feasible" category, the result of validation by material expert with the percentage feasibility $86,90 \%$ are in the "Very" Feasible" category and students assesment with the percentage feasibility 82,07\% are in the "Very Feasible"
\end{abstract}


category. Based on the results of the above, this developed media learning feasible to be used in concept and practice of Plumbing subject in Vocational Education of Building Construction.

Keywords: Interactive media learning, adobe flash, concept and practice of Plumbing.

\section{Pendahuluan}

Perkembangan ilmu pengetahuan dan teknologi (IPTEK) pada era globalisasi saat ini semakin pesat dari waktu ke waktu. Fenomena tersebut megakibatkan adanya persaingan dalam berbagai aspek dan bidang kehidupan manusia, salah satu diantaranya adalah bidang pendidikan. Untuk menghadapi persaingan tersebut, diperlukan peningkatan mutu pendidikan untuk mencetak sumber daya manusia (SDM) yang berkualitas.

Kemajuan ilmu pengetahuan dan teknologi (IPTEK) berpengaruh terhadap penggunaan alat-alat bantu mengajar di sekolah maupun di lembaga-lembaga pendidikan lainnya. Hujair dalam Muhson (2010: 1) berpendapat bahwa dewasa ini pembelajaran di sekolah mulai disesuaikan dengan perkembangan teknologi informasi, hal tersebut mengakibatkan perubahan dan juga pergeseran paradigma pendidikan. $\mathrm{Hal}$ ini mengindikasikan bahwa penggunaan teknologi informasi dalam proses pembelajaran sudah menjadi suatu kebutuhan sekaligus tuntutan di era globalisasi ini.

Dunia pendidikan dewasa ini memasuki era dunia media, di mana kegiatan pembelajaran menuntut dikuranginya metode ceramah dan diganti dengan pemakaian banyak media (Nurseto, 2011: 2). Jika mengacu pada perkembangan kurikulum saat ini, peserta didik tidak hanya berperan sebagai penerima pesan namun juga sebagai penyampai pesan sehingga terbentuklah komunikasi dua arah atau bahkan lebih. Dalam komunikasi tersebut, media pembelajaran dibutuhkan untuk meningkatkan efektivitas pencapaian dari sebuah pembelajaran.

Guna meningkatkan efektivitas dan efisiensi pembelajaran, perlu dikembangkan
Hal ini perlu dilakukan agar proses pembelajaran menarik, tidak monoton dan tidak membosankan sehingga tidak akan menghambat terjadinya transfer of knowledge. Oleh karena itu peran media dalam proses pembelajaran menjadi penting karena akan menjadikan proses pembelajaran tersebut menjadi lebih bervariasi dan tidak membosankan (Muhson, 2010: 1).

Berdasarkan hakikat proses pembelajaran, media pembelajaran merupakan saluran pesan, sedangkan penerima pesannya adalah peserta didik bahkan pendidik itu sendiri. Sebuah pesan dituangkan oleh pendidik atau sumber lain kedalam simbol-simbol komunikasi, baik secara verbal (kata-kata lisan ataupun tertulis) maupun non verbal atau visual (Setyawan, 2012: 2).

Media pembelajaran yang sering digunakan pada saat ini masih belum bisa meningkatkan efektivitas pencapaian hasil belajar karena kriteria pemilihan media pembelajaran kurang sesuai. Dalam memilih media untuk kepentingan pembelajaran menurut Sudjana \& Rivai (2002: 34) sebaiknya memperhatikan kriteria-kriteria sebagai berikut: a) Ketepatannya dengan tujuan pembelajaran. b) Dukungan terhadap isi bahan ajar. c) Kemudahan memperoleh media.

Saat ini masih sangat sedikit upaya untuk mengembangkan konten-konten pembelajaran. Kebanyakan konten pembelajaran masih dijelaskan secara lisan. Hal ini memunculkan adanya kebutuhan untuk pengembangan konten pembelajaran berbasis multimedia berupa media pembelajaran interaktif yang memanfaatkan unsur audio dan juga visual. Audio-visual adalah pembelajaran berbasis teknologi yang dapat digunakan sebagai sarana alternatif dalam mengoptimalkan proses pembelajaran, dikarenakan beberapa aspek 
antara lain: a) mudah dikemas dalam proses pembelajaran; b) lebih menarik untuk pembelajaran; dan c) dapat diperbaiki setiap saat. Melalui audio-visual pembelajaran dapat lebih interaktif dan lebih memungkinkan terjadinya two way traffic dalam proses pembelajaran (Haryoko, 2010: 2). Hal ini diharapkan dapat mewujudkan situasi pembelajaran yang lebih efektif dan meningkatkan kualitas proses belajar mengajar terutama pada pembelajaran Teori dan Praktik Plambing di Program Studi S1 PVKB UNJ.

Ada banyak media yang bisa membantu dalam proses pembelajaran, salah satunya dengan menggunakan perangkat lunak atau software komputer. Priyanto Hidayatullah dalam Priandana \& Asto (2015: 2) mengatakan kebanyakan software presentasi sekarang hanya sanggup menampilkan materi pelajaran secara statis.

Salah satu yang bisa menjadi alternatif adalah educational animation, yang kalau diambil pengertian sempitnya adalah visualisasi materi pelajaran dalam bentuk animasi untuk digunakan dalam kegiatan belajar mengajar. Media pembelajaran interaktif diatas dapat dibuat menggunakan software komputer yaitu Adobe Flash.

Software Adobe Flash digunakan sebagai pertimbangan untuk membuat media pembelajaran interaktif karena memiliki kelebihan salah satunya adalah dapat membuat simulasi yang diperlukan dalam proses belajar mengajar dan ukuran file yang dihasilkan relatif kecil. Sehingga proses belajar mengajar tidak monoton dengan presentasi yang hanya menggunakan tulisan dan gambar.

Pembelajaran Teori dan Praktik Plambing pada Program Studi Pendidikan Vokasional Konstruksi Bangunan UNJ bertujuan untuk menguasai standar kompetensi yang telah ditetapkan, sehingga dibutuhkan pemahaman yang cukup untuk melaksanakan pembelajaran terutama dalam melakukan praktiknya. Untuk meminimalisir ketidakpahaman dalam pembelajaran teori serta pelaksanaan praktik plambing tersebut, perlu digunakan media pembelajaran yang sesuai.

Berkembangnya ilmu plambing yang ada pada ranah teknik sipil membuatnya menjadi hal pokok yang harus ada pada bangunan. Hal itu diperkuat dengan adanya SNI 8153:2015 Tentang Sistem Plambing pada Bangunan Gedung dimana di dalamnya terdapat standar instalasi alat-alat plambing pada bangunan gedung. Sedangkan menurut Peraturan Menteri Pekerjaan Umum Nomor: 29/Prt/M/2006 Tentang Pedoman Persyaratan Teknis Bangunan Gedung terdapat persyaratan plambing dalam bangunan gedung dan persyaratan penyaluran air hujan. Berkaitannya kedua persyaratan tersebut maka sistem plambing penting untuk dipelajari, maka mata kuliah teori dan praktik plambing diharapkan mampu untuk meningkatkan pengetahuan mahasiswa mengenai sistem plambing.

Media pembelajaran yang digunakan dalam proses pembelajaran selama ini masih menggunakan metode presentasi dengan Powerpoint. Penggunaan media Powerpoint sangat bergantung kepada penyaji materi sehingga pembelajaran hanya berpusat kepada penyaji materi atau dosen. Hal tersebut mengakibatkan mahasiswa tidak dapat belajar secara mandiri.

Berdasarkan hasil pembelajaran Teori dan Praktik Plambing pada semester 106, hanya sebesar $15,4 \%$ yang mendapatkan A- s/d A. Hal tersebut mengidentifikasikan bahwa hasil pembelajaran yang dicapai belum maksimal. Sedangkan survey analisa kebutuhan yang telah dilakukan dan disebarkan pada angkatan 2013, 2014 dan 2015 Program Studi PVKB UNJ, didapatkan hasil bahwa sebesar 61\% mahasiswa menganggap bahwa media yang digunakan selama ini belum memenuhi kebutuhan sehingga dibutuhkan media pembelajaran baru yang lebih menarik dan interaktif. 
Berdasarkan uraian diatas, menarik kiranya untuk dilakukan penelitian tentang pengembangan bahan ajar berupa media interaktif dengan judul "Pengembangan Media Pembelajaran Interaktif pada Mata Kuliah Teori dan Praktik Plambing di Program Studi S1 PVKB UNJ"

\section{Identifikasi Masalah}

Berdasarkan uraian latar belakang yang telah dikemukakan sebelumnya, terdapat beberapa permasalahan yang dapat diidentifikasi sebagai berikut:

1. Apakah media pembelajaran pada mata kuliah teori dan praktik plambing yang selama ini digunakan dapat berfungsi secara efektif dalam proses pembelajaran?

2. Bagaimanakah hasil belajar teori dan praktik plambing di program studi S1 PVKB UNJ dengan menggunakan media pembelajaran saat ini?

3. Bagaimanakah pengembangan media pembelajaran interaktif pada mata kuliah teori dan praktik plambing dengan menggunakan perangkat lunak Adobe Flash?

\section{Pembatasan Masalah}

Berdasarkan latar belakang dan identifikasi masalah yang ada, pembatasan masalah dalam penelitian ini adalah:

1. Materi yang akan dikaji dalam media pembelajaran yang akan dikembangkan hanya menyangkut mata kuliah teori dan praktik plambing di Program Studi PVKB UNJ.

2. Materi yang akan disajikan dalam media pembelajaran interaktif ini hanya meliputi teori plambing untuk setengah semester.
3. Sasaran penelitian merupakan mahasiswa yang mengambil mata kuliah teori dan praktik plambing pada semester 108 .

\section{Rumusan Masalah}

Berdasarkan pada identifikasi masalah, maka perumusan masalah yang didapat adalah bagaimanakah pengembangan media pembelajaran interaktif pada mata kuliah Teori dan Praktik Plambing di Program Studi S1 PVKB UNJ?

\section{Kegunaan Hasil Penelitian}

Penelitian ini diharapkan dapat memberikan manfaat sebagai berikut:

1. Diharapkan konsep pembelajaran dengan menggunakan media interaktif dapat direkomendasikan sebagai inovasi dalam dunia pendidikan guna meningkatkan efektifitas pencapaian pembelajaran.

2. Diharapkan dapat digunakan sebagai acuan pengembangan media pembelajaran interaktif guna meminimalisasi ketidakpahaman dalam proses pembelajaran.

3. Sebagai ajakan untuk terus mengembangkan media pembelajaran alternatif.

4. Menjadi perangkat alternatif dalam pembelajaran mata kuliah Teori dan Praktik Plambing.

\section{Tinjauan Pustaka}

\section{Media Pembelajaran}

Kata media berasal dari bahasa Latin yang merupakan bentuk jamak dari 
"Medium", secara harfiah kata tersebut memiliki arti perantara, tengah atau pengantar. Menurut Anung Rachman, Vincent Suhartono (2014: 2) dalam aktivitas pembelajaran, media dapat didefinisikan sebagai suatu alat yang dapat membawa informasi dan pengetahuan dalam interaksi yang berlangsung antara pendidik dengan peserta didik. Sedangkan kata pembelajaran menurut Kamus Besar Bahasa Indonesia (KBBI) merupakan proses, cara, perbuatan menjadikan orang atau makhluk hidup belajar. Pengertian diatas diperkuat oleh Sukoco, Arifin, Sutiman, \& Wakid (2014: 2) yang mendefinisikan pembelajaran sebagai proses komunikasi yang dilakukan pendidik kepada peserta didik dalam rangka menyampaikan pesan tertentu.

Menurut Association for Educational Communications and Technology (AECT) media pembelajaran adalah segala sesuatu yang digunakan untuk menyampaikan pesan. Sedangkan menurut Miarso dalam Sudatha \& Tegeh (2009: 8) media pembelajaran adalah segala sesuatu yang digunakan untuk menyalurkan pesan serta dapat merangsang pikiran, perasaan, perhatian, dan kemauan si belajar sehingga dapat mendorong terjadinya proses belajar. Pernyataan tersebut juga didukung oleh Yudasmara \& Purnami (2010: 2) yang mengemukakan bahwa media berperan sangat penting sebagai pembawa informasi dari sumber (guru) menuju penerima (siswa). Untuk itu, penggunaan media yang tepat dan menarik akan menumbuhkan minat, rasa ingin tahu, motivasi dan kreativitas siswa, sehingga sangat penting untuk mengoptimalkan ketercapaian tujuan pembelajaran.

Berdasarkan pengertian tersebut dapat disimpulkan bahwa media pembelajaran merupakan suatu perantara yang digunakan oleh pendidik untuk menyampaikan pesan tertentu kepada peserta didik dalam proses belajar sehingga tujuan pembelajaran dapat tercapai secara optimal.

\section{Multimedia Pembelajaran}

Secara umum multimedia dapat didefinisikan sebagai gabungan atau kombinasi antara teks, gambar, animasi, suara dan video. Menurut Mayer (2014: 1) dalam penelitiannya yang berjudul "Incorporating Motivation into Multimedia Learning", pembelajaran multimedia meliputi kata dan gambar dan termasuk belajar melalui buku teks yang mengandung teks dan ilustrasi, pembelajaran dasar komputer yang mengandung animasi serta narasi dan slide presentasi tatap muka yang mengandung grafik dan kata-kata yang diucapkan. Sedangkan menurut Wiyana, Umar, \& Usman (2013: 5) multimedia adalah suatu multimedia yang dilengkapi dengan alat pengontrol yang dapat dioperasikan oleh pengguna, sehingga pengguna dapat memilih apa yang dikehendaki untuk proses belajar yang menarik sehingga dapat membentuk suatu konsep belajar yang tepat.

Pernyataan tersebut didukung oleh Sudatha \& Tegeh (2009: 51) yang mengemukakan bahwa istilah multimedia pembelajaran umumnya menunjuk pada semua software pendidikan yang diakses melalui komputer dimana siswa dapat berinteraksi dengannya. Sistem komputer menyajikan serangkaian program pengajaran kepada siswa baik berupa informasi maupun latihan soal untuk mencapai tujuan pengajaran tertentu dan siswa melakukan aktivitas belajar dengan cara berinteraksi dengan sistem komputer. Multimedia pembelajaran merupakan lingkungan belajar berbasis komputer yang memanfaatkan fleksibilitas komputer untuk memecahkan masalah-masalah belajar.

Berdasarkan definisi di atas, pengembangan media pembelajaran interaktif berbasis perangkat lunak komputer dapat dikategorikan sebagai multimedia pembelajaran karena menggunakan perangkat lunak komputer yang mengkombinasikan teks, gambar, animasi, suara dan video untuk proses 
pembelajaran sehingga dapat meningkatkan efektivitas pencapaian hasil dari suatu pembelajaran.

\section{Media Pembelajaran Interaktif}

Media secara umum merupakan suatu perantara dalam pembelajaran. Sementara media dalam bahasa Arab memiliki arti perantara atau pengantar pesan dari pengirim kepada penerima pesan. Sedangkan menurut Kamus Besar Bahasa Indonesia (KBBI), interaktif adalah sifat saling melakukan aksi, antarhubungan, saling aktif.

Berdasarkan pernyataan di atas, dapat disimpulkan bahwa media pembelajaran interaktif merupakan suatu perantara yang digunakan dalam proses pembelajaran dimana pengirim dan penerima pesan saling melakukan interaksi satu sama lain. Hal tersebut diperkuat oleh Arrosyida (2015: 3) yang menyatakan bahwa media pembelajaran interaktif adalah ssesuatu yang menyangkut software dan hardware yang dapat digunakan sebagai perantara untuk menyampaikan isi materi ajar dari sumber belajar ke pembelajar dengan metode pembelajaran yang dapat memberikan respon balik terhadap pengguna dari apa yang telah diinputkan kepada media tersebut.

\section{Tujuan Penelitian}

Tujuan dari penelitian ini adalah untuk mengembangkan perangkat media pembelajaran interaktif untuk mata kuliah teori dan praktik plambing yang dapat digunakan dalam proses pembelajaran.

\section{Metode Penelitian}

Penelitian ini dilakukan di Program Studi Pendidikan Vokasional Konstruksi Bangunan Universitas Negeri Jakarta pada tahun ajaran 2017/2018.

Penelitian ini merupakan penelitian pengembangan (research and development). Model pengembangan yang digunakan dalam penelitian ini mengadaptasi prosedur penelitian pengembangan Borg \& Gall yang dilakukan dengan pembatasan. Borg \& Gall dalam Emzir (2013: 271) mengatakan bahwa dimungkinkan untuk membatasi penelitian dalam skala kecil termasuk membatasi langkah penelitian. Penyederhanaan prosedur penelitian Borg \& Gall itu meliputi 5 langkah, yaitu sebagai berikut:

1. Penelitian Pendahuluan

Penelitian pendahuluan dilakukan untuk mengetahui kebutuhan pembelajaran yang ada di lapangan terkait dengan media pembelajaran yang digunakan. Maka dari itu dilakukanlah analisis kebutuhan sebagai data acuan untuk melakukan pengembangan media.

2. Mengembangkan Produk Awal

Pengembangan produk awal merupakan tahapan-tahapan yang dilakukan untuk membuat media pembelajaran interaktif. Tahap ini meliputi beberapa proses, yaitu desain data, desain interface, desain prosedural dan implementasi program.

3. Tahap Validasi Ahli

Validasi yang dilakukan terhadap media pembelajaran ini dilakukan oleh ahli media dan ahli materi. Validasi dilakukan untuk mengetahui apakah media pembelajaran yang dikembangkan layak digunakan dalam proses pembelajaran. Melalui tahap validasi ini akan diperoleh masukan dan 
kritik yang jelas guna memperbaiki media pembelajaran.

4. Tahap Uji Coba

Tahap ini dilakukan untuk mengetahui kualitas dari media pembelajaran yang telah dibuat. Data yang diperoleh dari hasil uji coba tersebut dapat dijadikan acuan untuk memperbaiki media pembelajaran.

5. Pembuatan Produk Akhir

Tahap ini merupakan hasil dari produk yang telah diperbaiki sesuai saran dan kritik dari para ahli serta data yang diperoleh dari tahap uji coba. Tahap akhir dari pembuatan produk adalah berupa media pembelajaran interaktif untuk mata kuliah Teori dan Praktik Plambing.

Teknik pengumpulan data yang digunakan pada penelitian ini adalah menggunakan kuesioner atau angket. Angket yang digunakan berupa angket untuk ahli media, ahli materi dan juga mahasiswa yang berfungsi untuk mengetahui tingkat kelayakan produk yang akan dikembangkan.

Teknik analisis data yang digunakan merupakan analisis deskriptif kualitatif. Teknik analisis dilakukan dengan mengelompokkan informasi dari data kualitatif berupa masukan, saran ataupun kritik terdapat pada angket. Melalui hasil analisis tersebut, media pembelajaran interaktif yang dikembangkan akan diperbaiki.

Persentase $=\frac{\text { Skor yang diobservasi }}{\text { Skor yang diharapkan }} \times 100 \%$

Data yang diperoleh dalam bentuk persentase tersebut kemudian dikonversi dengan menggunakan acuan tabel interpretasi kelayakan menurut Riduwan (2013: 22) seperti pada Tabel 1.

\section{Tabel 1. Interpretasi Skor Kelayakan Persentase Kriteria}

$\begin{array}{cc}\mathbf{0} \%-\mathbf{2 0} \% & \text { Sangat Tidak Layak } \\ \mathbf{2 1 \%}-\mathbf{4 0 \%} & \text { Tidak Layak } \\ \mathbf{4 1 \%}-\mathbf{6 0 \%} & \text { Cukup Layak } \\ \mathbf{6 1 \%}-\mathbf{8 0 \%} & \text { Layak } \\ \mathbf{8 1 \%}-\mathbf{1 0 0 \%} & \text { Sangat Layak }\end{array}$

\section{Pembahasan Hasil Penelitian}

Berdasarkan validasi yang telah dilakukan oleh ahli media dan ahli materi didapatkan hasil sebagai berikut: (1) Hasil validasi oleh ahli media menunjukkan persentase kelayakan sebesar $72,92 \%$ yang berada pada kategori "Layak"; (2) Hasil validasi oleh ahli materi menunjukkan persentase kelayakan sebesar $86,90 \%$ yang berada pada kategori "Sangat Layak"; (3) Hasil respon mahasiswa terhadap media mendapatkan persentase kelayakan sebesar $82,07 \%$ yang berada pada kategori "Sangat Layak"

\section{Hasil Pengembangan Media}

Pengembangan media pembelajaran interaktif ini menggunakan program Adobe Flash CS6 yang dikonversikan menjadi file ekstensi .exe.

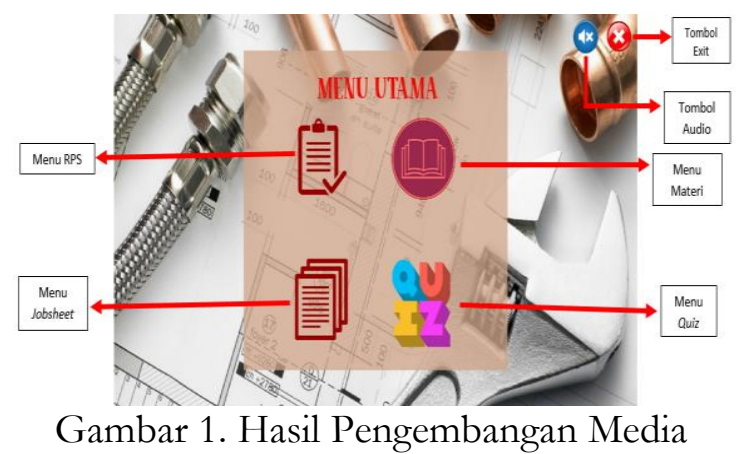

Hasil pengembangan media pembelajaran interaktif yang dikembangkan pada penelitian ini terdiri dari menu RPS, menu materi, menu jobsheet, menu quiz dan tombol-tombol navigasi diantaranya: tombol home, tombol exit, tombol audio, tombol kembali ke menu utama dan tombol next \& previous. 


\section{Kualitas Media}

Berdasarkan hasil validasi yang dilakukan oleh ahli media dan ahli materi serta respon mahasiswa terhadap media pembelajaran interaktif ini dapat disimpulkan bahwa kualitas media pembelajaran dilihat dari aspek media berada pada kategori "Layak", dari aspek materi berada pada kategori "Sangat Layak" dan respon dari mahasiswa berada pada kategori "Sangat Layak". Dari hasil data yang diperoleh, dapat disimpulkan bahwa media pembelajaran interaktif yang dikembangkan layak digunakan untuk proses pembelajaran.

\section{Kesimpulan}

Berdasarkan hasil penelitian dapat disimpulkan bahwa materi ajar Mata Kuliah Jurusan yang dibina oleh FT UNJ sebagian besar relevan dengan materi ajar yang dipelajari di sekolah.

1. Hasil yang diperoleh dari ahli media menunjukkan tingkat kelayakan media pembelajaran interaktif ini adalah sebesar $72,92 \%$ yang dapat dikategorikan bahwa media ini layak untuk digunakan.

2. Hasil yang diperoleh dari ahli materi menunjukkan tingkat kelayakan media pembelajaran interaktif ini adalah sebesar $86,90 \%$, hal tersebut dapat dikategorikan bahwa media ini sangat layak digunakan untuk pembelajaran.

3. Hasil dari uji coba kepada objek penelitian menunjukkan hasil bahwa media pembelajaran ini menarik minat mahasiswa untuk belajar dan dapat mempermudah mahasiswa dalam memahami materi.

\section{Saran}

Beberapa saran yang dapat diberikan berdasarkan hasil penelitian tentang pengembangan media pembelajaran interaktif adalah sebagai berikut:

1. Media pembelajaran interaktif ini dapat dimanfaatkan sebagai media pembelajaran alternatif dalam mata kuliah Teori dan Praktik Plambing.

2. Media pembelajaran interaktif ini dapat dikembangkan untuk penggunaan pada smartphone untuk pembelajaran.

\section{Daftar Pustaka}

Arrosyida, A., \& Suprapto. (2015). Media Pembelajaran Interaktif Jaringan Komputer Menggunakan Macromedia Flash 8 Di Smk Negeri 1 Saptosari. Jurnal Pendidikan Teknik. Informatika, (2), 1-8.

Emzir. (2013). Metode Penelitian Kualitatif Analisis Data. Jakarta: Rajawali Pers.

Haryoko, S. (2010). Efektivitas Pemanfaatan Media Audio-Visual Sebagai Alternatif Optimalisasi Model Pembelajaran, 5(1), 1-10.

Mayer, R. E. (2014). Incorporating Motivation Into Multimedia Learning. Learning and Instruction, 29, 171-173.

Muhson, A. (2010). Pengembangan Media Pembelajaran Berbasis Teknologi Informasi. Jurnal Pendidikan Akuntansi Indonesia, 8(2), 1-10.

Nurseto, T. (2011). Membuat Media Pembelajaran yang Menarik. Jurnal Ekonomi \& Pendidikan, 8, 19-35.

Priandana, V., \& Asto. (2015). Pengembangan Media Pembelajaran Multimedia Interaktif Berbantuan Software Macromedia Flash Pada Kompetensi Dasar Menerapkan Macam-Macam Gerbang Dasar Rangkaian Logika Di SMK Negeri 2 Bojonegoro. Jumal Pendidikan Teknik. 
Elektro, 04, 177-181.

Riduwan. (2013). Skala Pengukuran VariabelVariabel Penelitian. Bandung: Alfabeta.

Setyawan, A. (2012). Pengembangan Media

Pembelajaran Berbasis Adobe Flash

Professional Cs6 Pada Mata Kuliah

Hidrolika Di Jurusan Teknik Sipil dan

Perencanaan Universitas Negeri

Yogyakarta. Jurnal Ekonomi \& Pendidikan, 8(20), 58.

Sudatha, I. G. W., \& Tegeh, I. M. (2009). Desain Multimedia Pembelajaran, 104.

Sukoco, Arifin, Z., Sutiman, \& Wakid, M.

(2014). Pengembangan Media

Pembelajaran Interaktif Berbasis

Komputer Untuk Peserta Didik Mata

Pelajaran Teknik Kendaraan Ringan.

Jurnal Pendidikan Teknologi Dan Kejuruan, 22(2), 215-226.

Wiyana., Umar., \& Usman. (2013).

Pengembangan Multimedia Untuk

Perolehan Belajar Konsep Reproduksi

Manusia Dalam Mata Pelajaran Biologi

Kelas XI. Jurnal Teknologi Pendidikan, 1-

12.

Yudasmara, G. A., \& Purnami, D. (2010).

Pengembangan Media Pembelajaran

Belajar Siswa Smp, 1-8. Jurnal

Pendidikan dan Pengajaran 4 48, 1-8. 
Jurnal Pendidikan Teknik Sipil 